\title{
Palabras Extremas: Escritoras Gallegas e Irlandesas de
}

\section{Hoy}

Words from Afar: Galician and Irish Women Writers Today

\section{Katharina Walter}

\section{(2) OpenEdition \\ 1 Journals}

\section{Electronic version}

URL: http://journals.openedition.org/etudesirlandaises/1683

DOI: 10.4000/etudesirlandaises. 1683

ISSN: 2259-8863

\section{Publisher}

Presses universitaires de Caen

\section{Printed version}

Date of publication: 30 September 2009

Number of pages: $125-126$

ISBN: 978-2-7535-0982-5

ISSN: 0183-973X

\section{Electronic reference}

Katharina Walter, «Palabras Extremas: Escritoras Gallegas e Irlandesas de Hoy », Études irlandaises [Online], 34.2 | 2009, Online since 30 June 2011, connection on 21 September 2020. URL : http:// journals.openedition.org/etudesirlandaises/1683; DOI : https://doi.org/10.4000/etudesirlandaises. 1683

This text was automatically generated on 21 September 2020.

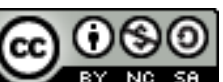

Études irlandaises est mise à disposition selon les termes de la Licence Creative Commons Attribution - Pas d'Utilisation Commerciale - Partage dans les Mêmes Conditions 4.0 International. 


\title{
Palabras Extremas: Escritoras Gallegas e Irlandesas de Hoy
}

Words from Afar: Galician and Irish Women Writers Today

\author{
Katharina Walter
}

\section{REFERENCES}

Palacios González Manuela, and Helena González Fernández, (eds). Palabras Extremas: Escritoras Gallegas e Irlandesas de Hoy (Words from Afar: Galician and Irish Women Writers Today), La Coruna, University Institute of Research in Irish Studies, 2008, 192 p., ISBN 978-84-9745-198-7

1 This collection of articles, essays and interviews maps out the field of comparative studies between contemporary Galician and Irish women's poetry, whereby in the past, according to the editors, Galician writers have often sought inspiration from their Irish fellows, while this interest has seldom been reciprocated. And indeed the various contributions to this volume of essays show that both bodies of poetry display many shared concerns, opening up new perspectives on concepts like 'femininity' and 'female embodiment', terms like 'literature' and 'nation', as well as foregrounding an interest in the natural world and its preservation.

2 Part I of this collection, "Naturaleza, Lenguaje y Mito" ("Nature, Language and Myth"), explores the negotiation of individual and collective identities through a renovation of the poetic devices available for the writing of land- and cityscapes, through a breach with the conventions of the poetic genre itself, as well as through a critical engagement with both native and foreign mythologies. Special emphasis is placed on attempts at remodelling the existent iconic representations of femininity within the discourses of mythology, nationalism and religion in both cultures, which in several contributions are shown to be contested for creating idealized, hypostasized images of womanhood that exclude the lived experience of female embodiment with its contingencies and continuous transformations. María Xesús Nogueira Pereira demonstrates that realistic, 
rather than idealized portrayals of various topographies predominate in the works of a wide range of Galician women poets published since the aftermath of the Spanish Civil War. Manuela Palacios González shows that a similar endeavour is present in contemporary Irish women's poetry, which renovates representations of women in relation to the natural world, bestowing agency on the conventionally passive female figures associated, for instance, with the traditional woman-as-nation trope. Helena González Fernández and Laura María Lojo Rodríguez analyze the ways in which Galician and Irish women poets renew language to reconceptualise elements of female identity, while María Xesús Lama López and Luz Mar González Arias focus on how contemporary Galician and Irish women's poetry redress elements of mythology, especially with regard to its female archetypes.

3 Part II of Palabras Extremas, "Con Voz Propia: Ensayos y Entrevistas" ("In Their Own Voices: Essays and Interviews"), provides a forum for Galician and Irish women poets to offer their thoughts on current cultural developments in their respective contexts, as well as on questions of literary norms and establishment. This section includes essays by the Galician María do Cebreiro and her Irish fellow poet Anne Le Marquand Hartigan, as well as interviews with Chus Pato, Ana Romaní, Mary O'Donnell and Celia de Fréine, which raise many similar problems outside the confines of the more conventionally academic analysis offered in the first section of the book.

4 Together the contributions in Palabras Extremas point to the vast and varied possibilities of comparison between Galician and Irish women's writing today, showing that both bodies of work share a concern with rewriting the traditions of portraying territory, myth, and female embodiment, both independently and in contexts where these domains intersect. Palabras Extremas has opened up an exciting new field of comparative analysis, and it can be hoped that the dialogue this collection has initiated will be extended and developed so as to strengthen the ties formed between these two rich and diverse cultures, and to enable more direct and integrated modes of communication between them. 